\title{
Tutkimuksen tila
}

Aikuiskasvatus ja ammatillinen koulutus ovat koulutusjärjestelmän kehittämisen tämän hetken tärkeitä työkenttiä. Yhteiskunnan ja työelämän muutokset asettavat ammattiopetukselle ja aikuiskasvatukselle suuret vaatimukset. Keskiasteen koulunuudistuksen ja aikuiskasvatuksen kehittämistyön on määrä luoda organisatoriset edellytykset sille, että yhteiskunnan kasvavat koulutustarpeet voidaan tyydyttäa. Asteittain koko koulutusjärjestelmä valmistetaan toteuttamaan jatkuvan kasvatuksen periaatetta. Kun koulutusjärjestelmä uudistuu, myös sen piirissä työskentelevät joutuvat uusimaan tietojaan ja taitojaan.

Vaikka vireillä olevat uudistukset ovat laajoja, pääkysymys kuitenkin on tulevan toiminnan sisältö, eivät sen hallinnolliset puitteet. Ammatillisen koulutuksen on kyettävä luomaan pätevyyksiä, joiden avulla kyetään hallitsemaan nopeasti kehittyviä työprosesseja, osallistumaan työtapojen kehittämiseen ja jatkamaan opintoja. Aikuiskasvatuksen on kyettävä vastaamaan moninaisiin, erilaisten elämäntilanteiden ja -perspektiivien luomiin sivistyksellisiin ja koulutuksellisiin tarpeisiin. Sen on kyettävä ratkaisemaan vaikeita sisällön valinnan ja metodisen toteutuksen ongelmia. Aiemmat käytännöt ja terve järki eivät riitä antamaan vastauksia näihin ongelmiin. Tarvitaan teoreettista tietoa ja tutkimusta.

Aikuiskasvatuksen ja ammattikoulutuksen uudistustyötä toteutetaan lähes ilman tutkimuksen antamaa tukea. Näiden alojen työntekijöiden ammattikäytännön kehittämiseksi ei myöskään ole tarjolla riittävää tieteellistä asiantuntemusta. Teorian ja käytännön hedelmälliseen vuorovaikutukseen ei ole mahdollisuuksia. Yhtenä syynä tähän on se, että maastamme on kokonaan puuttunut ammattikasvatukseen erikoistuneen kasvatustieteen professorin virka, ja aikuiskasvatuksenkin tutkimusta ja opetusta varten on ollut vain yksi professuuri. Tämän vuoksi on todella merkittävä asia, että lahjoitusvaroin on saatu Helsingin yliopiston kasvatustieteiden tiedekuntaan kasvatustieteen, erityisesti aikuiskoulutuksen professuuri ja Tampereen yliopiston kasvatustieteiden tiedekuntaan kasvatustieteen, erityisesti ammattikasvatuksen professuuri.

Uusien virkojen täyttöprosessi on kuitenkin tuonut kärkevällä tavalla esiin kysymyksen aikuiskasvatuksen ja ammattikasvatuksen tutkimuksen tilasta maassamme. Tieteelliset asiantuntijat eivät pitäneet ketäd̈n ammattikasvatuksen professorin virkaan hakeneista pätevänd̈ virkaan. Kaksi kolmesta asiantuntijasta piti myös kaikkia aikuiskoulutuksen professuuria ha- 
keneita epäpätevinä virkaan. Yksi asiantuntijoista sen sijaan arvioi kahden hakijan tieteellisen pätevyyden virkaan riittäväksi. Professorin virkaan hakeneiden tieteellisen pätevyyden arviointi on paitsi hallinnollinen toimenpide myös tilanne, jossa arvioidaan tieteellisin perustein alan tutkijoiden tuotantoa. Kaikki alan tutkimus ei luonnollisestikaan tule tällöin puntariin. On kuitenkin syytä otaksua, että merkittävä osa niistä, joilla on tieteellisiä ansioita ja ambitioita ko. aloilla, hakee virkaa. Talla perusteella edellä mainittujen virkojen täyttöprosessien yhteydessä annetut asiantuntijalausunnot antavat hälyttävän kuvan alan tutkimuksen heikosta tilasta maassamme. Meilla ei ole sellaisia elinvoimaisia, tieteellisesti korkeatasoisia ammattikasvatuksen eikä aikuiskasvatuksen tutkimuksen traditioita, jotka olisivat merkittävässä märin tuottaneet alalle uutta kehittäviä tiedemiehiä. Ei ole myöskään sellaista yleistä kasvatustieteellisen tutkimuksen traditiota, joka olisi luonut pohjan ammattikasvatuksen ja aikuiskasvatuksen erityisten kysymysten luovalle ja syvälliselle tutkimukselle.

Yksi syy siihen, että hakijoita ei ole katsottu virkoihin päteviksi, on se, että he eivät ole tutkineet virkojen erikoisalaan kuuluvia kysymyksiä. Erityisesti tämä tulee esiin ammattikasvatuksen kohdalla. Yksi asiantuntijoista toteaa lausunnossaan suostuneensa tehtäväan jonkin verran huolissaan siitä, että ammattikasvatus on hänelle vieras alue. Myöhemmin hän havaitsi sen olevan sitä myös viran hakijoille. Kukaan hakijoista ei ole ollut kiinnostunut ammattikasvatuksen yhteyksistd yhteiskuntaan ja sen tuotantorakenteen muutoksiin, ei myöskäan ammattikasvatuksen historiallisesta kehityksestad. Asiantuntija toteaa: "Ammattikasvatus - jonka laiminlyöty asema suomalaisessa kasvatustieteellisessä tutkimuksessa tulee mielestäni tämän viranhaun kautta näkyviin - on niin tärkeä alue tulevaisuuden kannalta, että ei ole tuntunut oikealta tinkid pätevyyskriteereistä." Samantapainen - joskaan ei aivan yhta heikko - on tilanne ilmeisesti aikuiskasvatuksen kohdalla.

Kasvatustiede liittyy monia muita tieteenaloja läheisemmin yhteiskunnalliseen käytäntöön. Aikuiskasvatuksen ja ammattikasvatuksen suhteellisen merkityksen korostuminen koulutusjarjestelmässä on ollut pitkäan näkyvissä. Se, että näihin alueisiin suuntautuvaa tutkimusta on tehty vähän, ei ehkä kerro vain kasvatustieteellisen tutkimuksen yhteiskunnallisten kytkentöjen kapeudesta. Se saattaa heijastaa myös teoreettisten lahtökohtien rajoittuneisuutta: omaksutut teoreettiset lähtökohdat eivät nosta esiin $k y$ - 
symyksiä, joita olisi välttämätöntä tutkia ammattiopetuksen ja aikuiskasvatuksen yhteydessä.

Tutkimuksen suuntautuneisuus ei ole ollut ainoa syy siihen, ettei hakijoiden tieteellistä pätevyyttä virkoihin ole pidetty riittävänä. Varsin suuri osa hakijoiden arvioitavaksi antamasta kirjallisesta tuotannosta ei asiantuntijoiden mukaan ole tieteellisesti merkittävää tutkimusta. Näin siitäkin huolimatta, että hakijoiden joukossa on myös kasvatustieteellisen professuurin haltija. Yksi ammattikasvatuksen professuurin täytössä asiantuntijana toimineista tiedemiehistä katsoi, että hänen arvioitavakseen annettua tuotantoa "vaivaa suuresti epäproblemaattisuus ja eräänlainen mekaanisuus, etten sanoisi dogmaattisuus'. ''Edelleen sitä vaivaa', näin asiantuntija toteaa, "eräänlainen abstrakti yksilökeskeisyys. Kirjoittajien ihmiset eivät elä missään todellisessa yhteiskunnassa, sellaisessa jolla olisi tietynlaiset taloudelliset rakennepiirteet, tietyllä tavalla kehittynyt teknologia ja ammattirakenne jne... Tutkimukset ovat lisäksi kovin ateoreettisia."' Asiantuntija arvostelee tutkimuksia myös siitä, että niissä ei suhteuteta omaa tehtyä tutkimusta meillä tai muualla aiemmin tehtyyn kasvatustieteelliseen tutkimukseen. Hakijat olisivat hänen mukaansa pystyneet parempaan, jos he olisivat määrän sijasta pyrkineet tietoisesti laatuun. Oireellista on ehkä sekin, että hyvin varteenotettavana seikkana joudutaan (syystä kyllä) pitämään sitä, että erään tutkijan arvioitavaan tuotantoon sisältyvä artikkeli on julkaistu kansainvälisessä aikakauslehdessä, ' 'kun ottaa huomioon, miten vähän suomalaiset kasvatustieteilijät julkaisevat tutkimuksiaan kansainvälisissä sarjoissa".

Asiantuntijalausunnot antavat kuvan tutkimuksesta, joka koostuu suurelta osin suppeista, irrallisista, empiirisistä töistä, 'jotka eivät muodosta kokonaisuutta, joka tekisi teorian systemaattisen kehittämisen mahdolliseksi"'. Osa tutkimuksista sisältää lisäksi ratkaisuja, jotka 'tutkimuksellisesti edustavat 'vähimmän vaivan' metodia, joka kasvatustieteessä on käynyt yleiseksi'”. Tällainen tutkimus ei voi täyttää kasvatustieteelliselle tutkimukselle tällä hetkellä asettuvia suuria tehtäviä. Siihen tarvittaisiin kansainvälisen teoreettisen keskustelun tasolla olevaa, teoreettisesti kunnianhimoista tutkimusta, tietoista pyrkimystä korkeaan tieteelliseen tasoon. Tämä edellyttää tutkimusta, joka on samanaikaisesti sekä entistä teoreettisempaa että entistä käytännöllisempää - teorian ja käytännön uudenlaista yhdistämistä tutkimuksessa.

Tieteellinen kritiikki on tiedeyhteisön keino huolehtia laadun tarkkailusta. Kriittistä keskustelua kasvatustieteen tutkimuksesta ja tutkimuspolitiikasta tarvitaan. Sitä tulisi käydä jatkuvasti tieteellisellä foorumeilla, ei vain virantäyttöprosessien yhteydessä. 